University of Miami Law School University of Miami School of Law Institutional Repository

2009

\title{
Irreconcilable Differences? The Troubled Marriage of Science and Law
}

Susan Haack

University of Miami School of Law, shaack@law.miami.edu

Follow this and additional works at: https://repository.law.miami.edu/fac_articles

Part of the Evidence Commons

\section{Recommended Citation}

Susan Haack, Irreconcilable Differences? The Troubled Marriage of Science and Law, 72 Law \& Contemp. Probs. 1 (2009).

This Article is brought to you for free and open access by the Faculty and Deans at University of Miami School of Law Institutional Repository. It has been accepted for inclusion in Articles by an authorized administrator of University of Miami School of Law Institutional Repository. For more information, please contact library@law.miami.edu. 


\title{
IRRECONCILABLE DIFFERENCES? THE TROUBLED MARRIAGE OF SCIENCE AND LAW*
}

\begin{abstract}
SUSAN HAACK**
In many respects [the scientific expert] seems to be a positive annoyance to lawyers, and even to judges at times, a sort of intractable, incompatible, inharmonious factor, disturbing the otherwise smooth current of legal procedure; too important or necessary to be ruled out, too intelligent and disciplined mentally to yield without reason to ordinary rules and regulations of the court,... and, at the same time[,] possessing an undoubted influence with the jury, that it is difficult to restrict by the established rules and maxims of legal procedure.

It is often said, with good cause, that ... the goal of a trial and the goal of science are ... at odds. ... [A] s a general rule, ... courts don't do science very well. ${ }^{2}$
\end{abstract}

I

\section{GETTING STARTED}

There was not a lot to be said for the miserable weeks after Hurricanes Katrina and Wilma-except, in retrospect, that all those hours spent sweating in the dark prompted some vivid thoughts about what life must have been like before electric light and power were available at the flick of a switch, and renewed my appreciation of the countless ways in which science now permeates just about every aspect of modern life.

"Every aspect of modern life" including, of course, the legal system. Legal proceedings now often rely significantly on scientific testimony, and scientific advisors contribute significantly to regulatory decisionmaking. ${ }^{3}$ Moreover, the

Copyright $(2009$ by Susan Haack.

This Article is also available at http://law.duke.edu/journals/lcp.

* First presented at the Fourth Coronado Conference organized by SKAPP (The Project on Scientific Knowledge and Public Policy), Bretton Woods, New Hampshire (May 3-4, 2007).

** Distinguished Professor in the Humanities, Cooper Senior Scholar in Arts and Sciences, Professor of Philosophy, Professor of Law, University of Miami. The author is grateful to Michele Taruffo and Mark Migotti for helpful comments on a draft, to Ken Williams for "effective assistance of colleague" with respect to "effective assistance of counsel," and to Barbara Brandon and Pamela Lucken for help in tracking down relevant material.

1. Charles F. Himes, The Scientific Expert in Forensic Procedure, 135 J. FRANKLIN INST. 407, 411$12(1893)$.

2. Edward Humes, Monkey GiRl: Evolution, EduCATION, Religion, and the BatTle FOR AMERICA'S SOUL 257 (2007).

3. See generally Symposium, Science in the Regulatory Process, 66 LAW \& CONTEMP. PROBS. 1 (Autumn 2003) (issue devoted to regulatory science). 
law regulates potentially hazardous scientific research; it may get involved when fraud is alleged in scientific work funded by government grants; ${ }^{5}$ and it may be called on to resolve disputes between scientific interests and interests of other kinds, for example, in "cultural heritage" cases such as the tussle over the fate of the 9,000-year-old skeleton of Kennewick Man, ${ }^{6}$ or in constitutional cases over high-school biology teaching.'

I shall confine myself here largely to scientific testimony in litigation; which, from the beginning, has prompted complaints both about the venality and dishonesty of scientific witnesses and about the scientific ignorance and credulity of jurors, attorneys, and judges. But some of what I have to say will also be relevant to the other contexts in which science interacts with the law; for the core of my argument will be that there are deep tensions between the goals and values of the scientific enterprise and the culture of the law, especially the culture of the U.S. legal system: ${ }^{8}$ between the investigative character of science and the adversarial culture of our legal system; between the scientific search for general principles and the legal focus on particular cases; between the pervasive fallibilism of the sciences-its openness to revision in the light of new evidence-and the concern of the law for prompt and final resolutions; between the scientific push for innovation and the legal system's concern for precedent; between the informal, problem-oriented pragmatism of scientific investigation and the reliance of the legal system on formal rules and procedures; and between the essentially theoretical aspirations of science and the legal system's inevitable orientation to policy.

The first step will be to sketch how the legal system began to use scientific experts, and how it has tried to accommodate their testimony to its own culture; the next, to understand what it is about the nature of science and the culture of law that makes the scientific expert, as Dr. Himes says, "a sort of intractable, incompatible, inharmonious factor, disturbing the smooth current of legal procedure"; then to illustrate how the tensions between science and the law reveal themselves in practice; and finally to comment, very briefly, on some efforts to alleviate the tensions.

4. See, e.g., Susan HaACK, Defending Science-Within Reason: Between Scientism AND CYNICISM 322-24 (2003) (discussing National Institutes of Health (NIH) regulation of early research on recombinant DNA).

5. For example, in the case of Dr. Eric Poehlman, who pled guilty to lying on a federal grant application and to fabricating data, over more than a decade, on obesity, menopause, and aging, see generally Jeneen Interlandi, An Unwelcome Discovery, N.Y. TIMES, Oct. 22, 2006, at 98; Plea Agreement, United States v. Poehlman, No. 2:05-CR-38-01 (D. Vt. Mar. 17, 2005); Sentencing Judgment, United States v. Poehlman, No. 2:05-CR-38-01 (D. Vt. June 30, 2005).

6. Bonnischen v. United States, 367 F.3d 864 (9th Cir. 2004); see also JEFF BENEDICT, NO BONE UNTURNED: THE ADVENTURES OF A TOP SMITHSONIAN FORENSIC SCIENTIST AND THE LEGAL BATTLE FOR AMERICA'S OLDEST SKELETONS (2003).

7. See, most recently, Selman v. Cobb County Sch. Dist., 390 F. Supp. 2d 1286 (N.D. Ga. 2005), and Kitzmiller v. Dover Area Sch. Dist., 400 F. Supp. 2d 707 (M.D. Pa. 2005). See generally HuMES, supra note 2 (telling the background story of Kitzmiller, and summarizing the trial proceedings).

8. Unless otherwise indicated, in what follows the phrase "the culture of the law" will refer specifically to the U.S. legal culture. 


\section{II}

\section{THE SCIENTIFIC WITNESS}

Of course, there haven't always been scientific witnesses; in fact, there haven't always been witnesses. In early medieval times, courts relied on tests by oath, ordeal, and sometimes (though in England, apparently, only rarely) by combat. ${ }^{9}$ A defendant in an action for debt, for example, might swear under oath that he owed nothing, and bring in "oath-helpers" or "con-jurors" to swear under oath that his statement under oath was not perjured. "[P]roof was not an attempt to convince the judges," Frederic Maitland writes, but "an appeal to the supernatural." This system of in-court tests-"proof" in the old sense of the word-rested on theologically based assumptions: that God would punish those who swore falsely, would ensure that an innocent defendant obliged to plunge his arm into boiling water was not scalded, and so on.

But by 1215, when the Fourth Lateran Council prohibited priests from participating in such tests, courts were gradually adopting other ways to proceed. ${ }^{12}$ On the Continent, the authorities turned to the Inquisition and to canonical law; in England, they turned to juries. ${ }^{13}$ The first jury trial was held in Westminster in 1220 , when five defendants who had been accused by a selfconfessed murderer in hopes of saving her own life agreed to submit to the judgment of twelve of their property-owning neighbors: ${ }^{14}$ and as the old system of in-court tests gradually fell into disuse, the new system of trial by jury gradually spread. However, in these early jury trials no witnesses were called; instead, jurors might go around town investigating for themselves, or might be specially chosen for their expertise-for example, a jury of vintners in a case in which a defendant was accused of selling bad wine, or a jury of butchers when the charge was selling putrid meat. ${ }^{15}$

And even when witnesses first began to be called, the system was still preadversarial, with witnesses serving not a party to the case, but the court. ${ }^{16}$ Gradually, however, the present adversarial practice developed, with witnesses prepared and presented by one party and cross-examined by the other, and formal rules restricting what evidence is admissible for the jury to hear. There

9. Frederic Williams Maitland, The Forms of ACtion at COMmON LAW 309 (1909).

10. Id.

11. Id.

12. See Paul R. Hyams, On the Laws and Customs of ENGland 101 (1981) (arguing that rejection of trial by ordeal "was at least a century and a half old in 1215 when the Fourth Lateran Council proclaimed the church's official disapproval").

13. MAITLAND, supra note 9 , at 311.

14. Four of the defendants were hanged; one was acquitted when the jurors swore he had not broken the law. SADAKAT KADRI, THE TRIAL: A HISTORY, FROM SOCRATES TO O.J. SIMPSON 69-70 (2005).

15. Learned Hand, Historical and Practical Considerations Regarding Expert Testimony, 15 HaRv. L. REV. 40, 41 (1901).

16. Stephan Landsman, Of Witches, Madmen and Product Liability: An Historical Survey of the Use of Expert Testimony, 13 BEHAV. SCI. \& L. 131, 135-38 (1995). 
had long been expert witnesses: courts had called on Latin scholars, for example, to help in construing unclear documents, and on physicians to give their opinions on the medicinal value of wolf-flesh in healing wounds, ${ }^{17}$ but now experts, like other witnesses, served the parties.

Learned Hand takes the essential characteristic of an expert witness, in the modern sense, to be that he is not bound by the "opinion rule," according to which a witness's conclusions are inadmissible.$^{18} \mathrm{He}$ dates the first appearance of such witnesses to 1620 , when in Alsop v. Bowtrell ${ }^{19}$ physicians testified that it was possible for a woman to bear a legitimate child "forty weeks and nine days" after the death of her husband. ${ }^{20}$ Stephan Landsman takes the more important point to be that expert witnesses are called by the parties and subject to crossexamination. ${ }^{21} \mathrm{He}$ suggests a later date, 1782, when in Folkes v. Chadd ${ }^{22}$ engineers appeared for each side in an action in which the plaintiff sought damages because a harbor had silted up, allegedly as a result of the construction of a bank to prevent flooding in a nearby meadow. ${ }^{23}$ (Tal Golan argues, however, that experts for the parties had been seen as early as $1678,{ }^{24}$ and that what was novel in Folkes $v$. Chadd was that the scientists involved relied on general, hypothetical scientific principles. $)^{25}$

As soon as the U.S. legal system came to rely significantly on scientific experts, complaints arose from all sides: expert witnesses-physicians especially-complained about the way they were treated under crossexamination; and both legal and scientific commentators expressed concern about the rise of what they perceived as a new class of partisan and untrustworthy professional experts. And as the use of scientific experts grew, so did the complaints. As early as 1858 , the Supreme Court was observing wryly that "experience has shown that opposite opinions of persons professing to be experts can be obtained in any amount",26 in 1874, John Ordronaux was complaining in the Journal of Insanity that "[f]atal exhibitions of scientific inaccuracy and self-contradiction... can not but weaken public confidence in

17. Id. at 133 .

18. Hand, supra note 15 , at 45.

19. Alsop v. Bowtrell, Cro. Jac. 541, 541 (1620).

20. Hand, supra note 15, at 45 (noting that the expert witness, as an exception to the opinion rule, is a kind of relic left over from the older system, before the opinion rule limited lay witnesses' testimony).

21. Landsman, supra note 16 , at 141.

22. Folkes v. Chadd, 3 Doug. 157, 157-58 (1782); JAMEs ThAYeR, Select CaSes ON EvidenCE AT THE COMMON LAW 666 (1892).

23. Landsman, supra note 16, at 141.

24. Tal Golan, Laws of Men and Laws of Nature: THE History of SCIENTIFIC ExPERT Testimony in England AND America 41 (2004) (citing Rex $v$. Pembroke (1678) in 7 CobBetT's COMPlete COllection of State Trials and ProceEdings for High Treason and Other CRIMES AND MISDEMEANORS FROM THE EARLIEST PERIOD TO THE PRESENT TIME 185-86 (Thomas J. Howell ed., London, R. Bagshaw 1810)).

25. Golan, supra, note 24 , at $43-44$.

26. Winans v. N.Y. \& Erie R.R. Co., 62 U.S. 88, 101 (1858). 
the value of all such evidence", ${ }^{27}$ in 1884 , the court in Ferguson v. Hubbell ${ }^{28}$ advised that expert testimony "should not be much encouraged and should be received only in cases of necessity," because their opinions "cannot fail generally to be warped by a desire to promote the cause in which they are enlisted", ${ }^{29}$ in 1893, Dr. Himes observed that scientific witnesses "are selected on account of their ability to express a favorable opinion, which, there is great reason to believe, in many instances [is] the result ... of [their] employment [as witnesses], and the bias growing out of it",30 and in 1910, a contributor wrote in the Yale Law Journal that "[t]here is constant complaining and mistrust on the part of the judges, juries and lawyers of the expert witness." ${ }^{31}$

In 1925, John Scopes was convicted of teaching evolution to a high-school biology class, in contravention of Tennessee's Anti-Evolution Act. ${ }^{32}$ Clarence Darrow had recruited a whole team of scientific experts to testify in Scopes's defense, but the judge excluded all but one of them. At the time, "nationally accepted court rules discouraged expert testimony." ${ }^{33}$ In fact, what is now seen as a key move to domesticate scientific testimony in the legal context had been made a couple of years before, when in Frye v. United States ${ }^{34}$ the Court of Appeals for the District of Columbia gave a test to determine, not just whether a scientific witness was qualified to testify, but whether novel scientific testimony was good enough for the jury to hear: the "scientific principle or discovery" on which that testimony was based must be "sufficiently established to have gained general acceptance in the field to which it belongs. ${ }^{35}$ It was decades before the "Frye Rule" began to spread, but by the early 1980s it had become the accepted standard in many states; and it remains so to this day in the District of Columbia and in a number of states, including California, New York, Pennsylvania, and Florida. ${ }^{36}$

27. John Ordronaux, On Expert Testimony in Judicial Proceedings, 317 J. INSANITY 317 (1874). At the time, Ordronaux was a member of the State Commission in Lunacy. Obituary, Dr. John Ordronaux, N.Y. TIMES, Jan. 21, 1908.

28. Ferguson v. Hubbell, 97 N.Y. 507, 514 (N.Y. 1884).

29. Id.

30. Himes, supra note 1, at 409; see also supra text accompanying note 1 .

31. Lee M. Friedman, Expert Testimony, Its Abuse and Reformation, 19 Y ALE L.J. 247, 247 (1910).

32. Scopes v. State, 278 S.W. 57,57 (Tenn. 1925).

33. EDWARD J. LARSON, TRIAL AND ERROR: THE AMERICAN CONTROVERSY OVER CREATION AND EVOLUTION 68 (3d ed. 2003) (citing THOMAS STEWART \& ARTHUR GARFIELD HAYES, THE WORLD'S MOST FAMOUS COURT TRIAL: STATE OF TENNESSEE V. JOHN THOMAS SCOPES 137, 150-53 (Leonard W. Levy ed., Da Capo Press 1971) (1925); 3 DAVID W. Louisell \& CHRISTOPHER B. Mueller, Federal EVIDENCE 629-30, 633, 649-56, 687-88 (1979); 3 JaCK B. Weinstein \& MARGARET BERGER, WEINSTEIN'S EVIDENCE 702-03 (1982)). In Kitzmiller, a whole parade of expert witnesses, on both sides, dominated the proceedings. Kitzmiller v. Dover Area Sch. Dist., 400 F. Supp. 2d 707 (M.D. Pa. 2005).

34. 293 F. 1013 (D.C. Cir. 1923).

35. Id. at 1014 .

36. Alice B. Lustre, Annotation, Post-Daubert Standards for Admissibility of Scientific and Other Expert Evidence in State Courts, 90 A.L.R. 5th 453 (2001). Michigan stuck with Frye until 2004, when it shifted to Daubert. MiCH. R. Evid. 702 (2003); People v. Wright, No. 261380, 2006 WL 2271264 at *5 
In 1975, the Federal Rules of Evidence were adopted. Rule 702, on expert testimony, said nothing explicit about "general acceptance," only that a qualified expert may testify provided that his or her evidence is relevant to facts at issue, and not otherwise legally excluded. ${ }^{37}$ In 1993, the Supreme Court's ruling in Daubert ${ }^{38}$ established that in federal jurisdictions the new Rule 702 had superseded Frye, but also that federal courts' "gatekeeping" role nevertheless requires them to screen proffered expert testimony for reliability as well as for relevance..$^{39}$ In 1997, the Court confirmed in Joiner that the standard of review for such evidentiary rulings is abuse of discretion $;^{40}$ and in 1999 , the Court confirmed in Kumho that Daubert covers all expert testimony, not only the scientific." In 2001, Rule 702 was revised to require that expert testimony be based on "sufficient facts or data," arrived at by "reliable principles and methods" "reliably" applied to the facts of the case. ${ }^{42}$

Still, despite all these efforts, I don't suppose anyone for a moment imagines that all the problems are now fully resolved. The Daubert ruling is far from unambiguous; its philosophical underpinnings are far from sound ${ }^{43}$ and its articulation of the idea of evidentiary reliability is far from transparent. ${ }^{44}$ Moreover, though Justice Blackmun's rhetoric suggested that the intent was to relax the standards of admissibility, ${ }^{45}$ in civil cases the upshot seems to have been to restrict them. ${ }^{46}$ The Joiner ruling distances itself somewhat from

(Mich. App. Aug. 8, 2006), ("MRE 702 was specifically amended, effective January 1, 2004, to incorporate the Daubert standards.").

37. FED. R. EVID. 702 (1975) ("If scientific, technical, or other specialized knowledge will assist the trier of fact to understand the evidence or to determine a fact at issue, a witness qualified as an expert by knowledge, skill, experience, training, or education, may testify in the form of an opinion or otherwise.").

38. Daubert v. Merrell Dow Pharms., Inc., 509 U.S. 579 (1993).

39. Id. at 589 ("[The Frye Rule is an] austere standard, absent from, and incompatible with, the Federal Rules of Evidence, [and] should not be applied in federal trials.").

40. Gen. Elec. Co. v. Joiner, 522 U.S. 136, 139 (1997) ("We hold that abuse of discretion is the appropriate standard.").

41. Kumho Tire Co. v. Carmichael, 526 U.S. 137, 141 (1999) ("We conclude that Daubert's general holding - setting forth the trial judge's 'gatekeeping' obligation-applies not only to testimony based on 'scientific' knowledge, but also to testimony based on 'technical' and 'other specialized' knowledge.").

42. FED. R. EVID. 702 (2001) ("If scientific, technical, or other specialized knowledge will assist the trier of fact to understand the evidence or to determine a fact in issue, a witness qualified as an expert by knowledge, skill, experience, training, or education, may testify thereto in the form of an opinion or otherwise, if (1) the testimony is based on sufficient facts or data, (2) the testimony is the product of reliable principles and methods, and (3) the witness has applied the principles and methods reliably to the facts of the case.").

43. See generally Susan Haack, Trial and Error: The Supreme Court's Philosophy of Science, 95 Am. J. Pub. Health (Supplement 1) S66 (2005).

44. See generally Susan Haack, Peer Review and Publication: Lessons for Lawyers, 36 STETSON L. REV. 789, 811 (2007).

45. Daubert v. Merrell Dow Pharms., Inc., 509 U.S. 579, 589 (1993).

46. See Lisa Heinzerling, Doubting Daubert, 14 J.L. \& POL'Y 65, 68 (2006) ("[T]he [Daubert] Court's casually offered guidelines on admitting expert scientific evidence have served as the vehicle for transforming Daubert from an evidence-liberalizing decision into an evidence-narrowing one."); 
Daubert's muddled philosophy of science-but creates further concerns about the blurring of questions of admissibility with questions of the weight or the sufficiency of evidence; the Kumho Tire ruling finally acknowledges that what really matters is not whether expert testimony is science, but whether it is reliable-yet it seems to leave all the tricky stuff to courts' discretion. And the revised Rule 702, with its emphatic repetition of "reliable," "reliably," and "sufficient," is is apt to leave one doubtful whether any verbal formula, by itself, could make it possible to determine whether the data on which a scientific witness bases his opinion are sufficient, or whether his methods are reliable.

So it comes as no surprise that the old complaints about tainted, partial experts and ignorant, credulous attorneys, jurors, and judges are still heardand now, also, a new complaint, as would-be scientific witnesses whose testimony has been ruled inadmissible by a court protest the professional insult of being "dauberted out" when a judge deems their proffered testimony unreliable, even "unscientific." experts, attorneys who encourage such experts into the legal system, gullible jurors overimpressed by the supposed authority of a witness merely on account of his scientific credentials, and scientifically illiterate judges too ready to dismiss an expert witness's unwelcome proffered testimony as not really science at all. But underlying these familiar complaints are the "irreconcilable differences" to which my title alludes: deep tensions between the goals, the processes, the values, and the timetable of scientific inquiry, and legal goals, processes, values, and schedules.

\section{III}

\section{THE NATURE OF SCIENCE AND THE CULTURE OF LAW}

It is sometimes said that science is a search for truth; and this is right, if rightly understood. The core business of the sciences is inquiry; the object of the enterprise is to figure out answers to questions about the world and how it works. Of course, it goes without saying that whenever one wants answers to questions, one wants true answers. This is not to say that scientists seek THE TRUTH, in some quasi-religious sense; nor is it to suggest that scientific truths are the only truths, or that scientific truths are ever known with absolute certainty. ${ }^{49}$ But it is to say that when, for example, James Watson and Francis

Susan Haack, Of Truth, in Science and in Law, 73 BROOK. L. REV. 985, 990 (2008) (commenting on the effects of Daubert in civil trials).

47. FED. R. EvID. 702 (2001).

48. George Lakoff, A Cognitive Scientist Looks at Daubert, 95 AM. J. PUB. HEALTh (SUPPLEMENT 1) S114, S117 (2005) ("When a scientist is 'Dauberted out' of a trial, the repercussions for the scientist are serious."); De-Daubertizing Economic Damages Evidence, LOSTCOMPENSATION.COM, Jan. 2006, available at http://www.lostcompensation.com/newsletters/v3_i1_2006.html ("A 'dauberted out' economic expert in injury and wrongful death cases can be particularly disastrous.").

49. It is, however, to reject both the instrumentalist view that theoretical "statements" in science are not really genuine statements at all, and so are neither true nor false, and the constructiveempiricist view that, although theoretical statements are statements, and do have truth-values, the goal 
Crick worked to "solve the structure of DNA," what they wanted was to reach the answer that DNA is a double-helical, backbone-out macromolecule with like-with-unlike base pairs if DNA is a double-helical, backbone-out macromolecule with like-with-unlike base pairs, to reach the answer that DNA is a triple-helical backbone-in macromolecule with like-with-like base pairs if it is a triple-helical backbone-in, macromolecule with like-with-like base pairs, and so on.

As the example suggests, once scientists have figured out the answer to one question, new questions almost invariably arise-sometimes a whole cascade of them: as, once they had worked out the structure of DNA, molecular biologists next had to tackle the "Coding Problem," which it would take more than a decade to solve. ${ }^{50}$ And as this in turn suggests, even though there is no guarantee that every step will be in the right direction, it is in the nature of the scientific enterprise to push forward, to tackle new questions with the help of answers to older ones.

Of course, scientists seek not just true answers, but substantive, explanatory answers ("either DNA is a double-helical, backbone-out macromolecule with like-with-unlike base pairs, or not," though undeniably true, won't do). Although scientific investigation sometimes focuses on particular things or events-a particular planet, earthquake, eclipse, epidemic, or whatever-even when it does, there is always a concern with laws, explanation, prediction; in short, with the general. Medical scientists, for example, might investigate why this individual seems unusually resistant to HIV infection; but the goal would be to figure out what it is about him that makes him less susceptible.

Like historians, investigative journalists, detectives, ${ }^{51}$ or anyone seriously trying to figure something out, scientists make informed guesses at the answers to their questions, work out their consequences, seek out evidence to check how well those consequences hold up, and use their judgment as to how to proceed from there. There is no algorithmic "scientific method," no formal, or formalizable, procedure available to all scientists and only to scientists, which, faithfully followed, guarantees success, or even progress. But over centuries of work, scientists have gradually developed a vast array of special tools and techniques: ever more-powerful instruments of observation, ever more-cunning (and sometimes very formally precise) experimental designs, ever moresophisticated mathematical and statistical techniques, ever fancier computer programs, and so on. These scientific "helps" to inquiry usually develop in an ad hoc way, in response to some problem at hand; and almost always they rely on

of science is empirical (in other words, observational) adequacy, not truth. I shall not argue either point here, but refer readers to the arguments in HAACK, supra note 4, at 137-41.

50. Horace freeland Judson, The Eighth Day of Creation: Makers of the REVOLUTION IN BIOLOGY 488 (1979).

51. Nowadays, however, police detectives (and doubtless many private investigators too) will also usually be concerned that they obtain evidence in such a way that it will be admissible in court. 
some earlier scientific innovation, theoretical or practical. ${ }^{52}$ The evolution of such "technical" helps to inquiry has been an untidy, pragmatic, fallible, bootstrap process that has gradually made it possible to get more and betterfocused evidence and to assess more accurately where evidence leads - in short, to extend and amplify unaided human cognitive powers.

Because the core business of science is inquiry, the core values of science are epistemological: honesty, with oneself and others, about what the evidence is and what it shows, and willingness to make that evidence available to others in the field-essentially the values Robert Merton articulated long ago under the labels "disinterestedness" and "communism." Instilling and sustaining commitment to these values isn't easy; scientists are fallible human beings, with the usual, mixed and sometimes dubious motives, hopes, and fears. Still, besides those technical helps, the sciences have developed informal social mechanisms to enable the pooling of evidence and to provide incentives and disincentives, which, up to a point, harness less-admirable motives, such as vanity or the desire for prestige, to serious scientific work. ${ }^{54}$ However, while the technical helps enabling scientists to acquire and assess evidence keep getting better and better, these "social" helps do not; in fact, they are coming under increasing strain both from the ever-growing scale of the scientific enterprise and from the alien values of the governments and large industrial concerns on whose financial support science increasingly depends-especially in the most commercialized areas of science, the medical sciences in particular.

Where all but the very simplest scientific claims and theories are concerned, the evidence will ramify in all directions; it is usually mediated by sophisticated instruments; more often than not it is the shared resource of many people, who may be working together or may be rivals, and who may be working in the same laboratory or thousands of miles or many decades or even centuries apart; it is almost invariably incomplete; and it is quite often ambiguous or misleading. At any time, some scientific claims and theories are so well-established that it would be astounding if they turned out to be wrong, some well- but not quite so

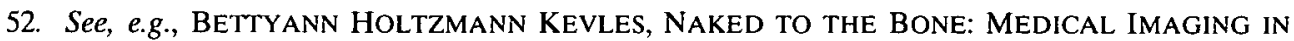
THE TWENTIETH CENTURY (1997) (presenting a history of medical-imaging techniques).

53. ROBERT K. MERTON, SOCIAL THEORY AND SOCIAL STRUCTURE 307 (1949). Merton's understanding of science is nowadays regarded in some circles as hopelessly passé, but others believe, on the contrary, that some insights of Merton's are now in danger of being lost. See also HAACK, supra note 4, at 299-328 (discussing the values of science); SUSAN HAACK, The Integrity of Science: What It Means, Why It Matters (1996), in PUTTING PHILOSOPHY To Work: INQUIRY AND ITS PLACE IN CULTURE 106 (2008) (adopting and developing some of Merton's ideas about the norms of science).

54. Some professional scientific organizations now have formal codes of ethical conduct. See, e.g., America Society of Microbiology, http://www.asm.org/general.asp?bid=14777 (last visited Feb. 3, 2009); Gerontological Society of America, http:/www.geron.org/Membership/Code\%20of\%20Ethics/37Membership/131-code-of-ethics (last visited Feb. 3, 2009); International Union of Biochemistry and Molecular Biology, www.babonline.org/bab/babcethics.pdf (last visited Feb. 3, 2009); American Medical Association, http://www.ama-assn.org/ama/pub/category/2512.html (last visited Feb. 3, 2009) (stating the "9 principles of conduct" that define physicians' behavior and are the basis for the opinions that make up the Code of Medical Ethics). Courses in ethics for science students are not uncommon; but more formal arrangements like these cannot compensate for an erosion of the ethos of science. 
well-established, some rather speculative, some very speculative, some highly speculative, and some downright wild and wacky. The proportion of the wellwarranted to the highly speculative varies, obviously, from field to field, with some areas of science thus far more speculative than others, and some, arguably, thus far mostly speculative; for some fields of science are more advanced more "mature," as we say, others relatively new and thus-far undeveloped, and some so undeveloped, so entirely speculative, that one might understandably hesitate to call them "sciences" at all. The boundaries of the enormously complex and uneven enterprise referred to by the commodious word "science" are fuzzy, indeterminate, and frequently contested.

When the available evidence on some scientific question is seriously incomplete, those who work in the relevant scientific community-some of them probably more radical in temperament, others more conservative-may reasonably disagree about the likelihood that this or that answer is correct. As new evidence comes in, a consensus may eventually form that this once merely speculative theory is probably right, or that that once seemingly promising approach probably wrong. But there are no rules determining when a scientific claim is well enough warranted by the evidence to be accepted, or badly enough undermined by the evidence to be rejected; and neither, of course, do scientists reach their "verdict" by taking a vote. ${ }^{55}$ Instead, consensus arises as a byproduct when enough members of the relevant scientific subcommunity come to see the evidence as strong enough to warrant this claim or that theory.

Ideally, such consensus would form when, and only when, the evidence is sufficient; in practice, acceptance and warrant sometimes come apart. ${ }^{56}$ This may be because significant evidence gets lost or neglected ${ }^{57}$ it may be because some widely held but unwarranted assumption skews scientists' judgment ${ }^{58}$ or it may be the result of the influence or the persuasiveness of some individual or group

55. The recent vote by an international congress of astronomers to demote Pluto from the status of planet was a vote to adopt the verbal convention that to count as a planet, a heavenly body should have these and those characteristics; it was not a vote that Pluto lacks certain of these characteristics-which is simply not the kind of thing that could be so decided. Dennis Overbye, Astronomers in Quandary Over Pluto's Planet Status, N.Y. Times, Aug. 23, 2006, at A20; Kenneth Chang, Dwarf Planet, Cause of Strife, Gains "the Perfect Name," N.Y. TIMES, Sept. 15, 2006, at A20.

56. Perhaps the first phrase of the Frye Rule, that the underlying scientific principle must be "sufficiently established to be generally accepted in the field," was an implicit acknowledgment of this possibility. If so, it is an insight that is lost when the Rule is abbreviated, as it usually is, to "general acceptance." This prompts the speculation that the Florida Supreme Court's ruling in Ramirez III-where it seems on its face as if the court conducted a Daubert inquiry to determine the kind of knife-mark identification on which Mr. Ramirez's conviction turned is generally accepted in the field-might more plausibly be read as implicitly recognizing the significance of this initial phrase of the test proposed in Frye. Ramirez v. State, 810 So.2d 836, 845 (Fla. 2001).

57. Gregor Mendel's paper, effectively establishing the particulate theory of inheritance, lay neglected and unread in the journal of the Natural History Society of Brno (Brünn), Moravia, for decades. Frank Maloney, Gregor Johann Mendel O.S.A., Villaṇova University, available at http://astro4.ast.vill.edu/mendel/gregor.htm (last visited Oct. 26, 2008).

58. See JUDSON, supra note 50, at 608-13 (discussing Phoebus Levine's tetranucleotide hypothesis, which, though merely a conjecture, was so widely accepted as to hold back recognition that DNA is the genetic material). 
in the field. ${ }^{59}$ But what counts in the end is not what person is most powerful or most persuasive, but what approach proves most fruitful, which theory proves to stand up best as evidence comes in. Watson really wanted to beat out Linus Pauling and win a Nobel prize, but it would not have satisfied him to win simply by being more persuasive than Pauling was; the point was to solve the structure of DNA first. Had he aimed only to win the debate, only to persuade others to his point of view, he would have been engaged in sham inquiry, that is, in advocacy disguised as investigation, not the real thing. ${ }^{60}$ Indeed, as Michael Polanyi once put it, "Only if scientists remain loyal to scientific ideals rather than try to achieve success with their fellow scientists can they form a community which will uphold those ideals." ${ }^{\prime 61}$

Though some science is certainly policy-relevant, scientific investigation is, in an important sense, policy-neutral. ${ }^{62}$ Scientists may, for example, explore the risks and benefits of making this or that drug or pesticide available, or the longrun effects of damming that river or of relying on this rather than that energy source; but whether the risks of the drug outweigh the benefits, whether the river should be dammed, whether we should switch to an alternative energy source, are not themselves scientific questions. However, when scientific work bears closely on policy questions, the line between scientific inquiry and policy advocacy can too easily get blurred.

Quite often, a scientist or scientific team will need to come up with some kind of answer on a specific timetable, as when they are working under pressure in an epidemic or in wartime ${ }^{63}$ or simply because they need to report some result at the end of the grant period to the outfit that funded them. But in such circumstances the work is very apt to be skimped; for the unavoidable fact is

59. This is apparently what happened in Soviet biology in the decades in which it was impeded by the influence of Trofim Lysenko's politically convenient, but badly mistaken, ideas. On the history of Soviet biology in the Lysenko period, see, for example, WILliam BROAD \& NICHOLAS WADE, BETRA YERS OF THE TRUTH 186-92 (1982); GEORGE S. COUNTS \& NuCIA LODGE, THE COUNTRY OF THE BLIND: THE SOVIET SySTEM OF MIND CONTROL (1949); NILS Roll-HANSEN, THE LYSENKO Effect: The Politics of SCience (2005); Valery N. Soyfer, The Tragedy Of Soviet SCIENCE (Leo Gruliow \& Rebecca Gruliow trans., 1994).

60. See SUSAN HAACK, "As for that phrase 'studying in a literary spirit' . . ," in MANIFESTO OF A PASSIONATE MODERATE: UNFASHIONABLE ESSAYS 48-68, 188-208 (1998) (developing from Charles S. Peirce the idea of sham inquiry). The "Wedge Document," produced by the Center for Science and Culture at the Discovery Institute and made public-apparently without the Center's authorization-in 1999, resembles nothing so much as a marketing plan for Intelligent Design Theory. This document gives the lie to the pretense that IDT is a scientific conjecture giving rise to a bona fide research program. Center for the Renewal of Science and Culture, The Wedge Strategy, available at www.kcfs.org/Fliers_articles/Wedge.html (last visited Oct. 26, 2008); see also BARBARA FORREST \& Paul R. Gross, Creationism's Trojan Horse: The Wedge of INTElligent Design (2004) (criticizing Intelligent Design Theory generally, and the Discovery Institute's Wedge Document specifically).

61. Michael Polanyi, SCiEnCE, Faith AND Society 40 (1946).

62. Some might argue that political science is an exception, but this is not an issue that can be pursued here.

63. See JOHN BARRY, THE GREAT INFLUENZA (2004) (a history of the hurried work to figure out the cause of the 1918 flu epidemic); WILliAM COOPER, THE STRUGGLES OF ALBERT WOODS (1952) (a fictional account of hurried poison-gas research during World War II). 
that scientific inquiry takes the time it takes, and its progress is ragged and unpredictable. It may be possible to say ahead of time how long it will take to run this series of experiments, or how long that epidemiological study will continue; but even the best-informed specialist can make only very tentative and fallible estimates of how long it might be before this problem is solved, that natural phenomenon understood. Moreover, at any time there are many scientific questions to which there is no warranted answer, and to which scientists can only say, "at the moment, we just don't know; we're working on it, but we can't tell you when we will have it figured out."

I have stressed that the core business of science is inquiry; but not all those who describe themselves as scientists are engaged in this core business (and most of those who are will likely be engaged in fairly routine kinds of investigation, not in the profound intellectual work of the heroes of the history of science). Some scientists are mostly occupied with developing new instruments, new techniques of purification, new computer programs, and so forth and so on; another large class of people who might be described as engaged in "scientific work" in an ample sense of that phrase are simply applying well-established scientific techniques in relatively routine kinds of testing; and some have borrowed the honorific description "science" for no better reason than that they rely on scientific equipment of one kind or another-or just because it makes their work seem more respectable. ${ }^{64}$

Nevertheless, the core business of science is inquiry. And scientific inquiry is by nature tentative and thoroughly fallibilist; it focuses on the general law or principle rather than on the particular case; its core values are intellectual honesty and willingness to share evidence; its procedures are problem-oriented and informally pragmatic; it is open-ended and forward-looking; and, though it is quite often relevant to policy, it is policy-neutral. So it is hardly surprising that the legal system has had trouble handling scientific testimony, for the legal culture could hardly be more different: adversarial; focused on the specific case; formally procedurally anchored; valuing promptness and finality; relying on precedent; and not only relevant, but also sensitive, to policy.

Justice Blackmun writes in Daubert that there are "important differences between the quest for truth in the courtroom and the quest for truth in the laboratory."65 That's putting it mildly. The core business of a legal system is to resolve disputes; and a trial aims not to find out whether the defendant is guilty or liable, but to arrive at a determination of the defendant's guilt or liability"determine," here, probably being closer to "deem" than to "discover." This is not to deny that inquiry plays a role in the legal process-of course it does; ${ }^{.6}$ nor

64. Or, as in the case of "creation science," in hopes of circumventing legal problems.

65. Daubert v. Merrell Dow Pharms., Inc., 509 U.S. 579, 596-97 (1993).

66. Failure to investigate is one criterion of "ineffective assistance of counsel" in death-penalty cases. See Rompilla v. Beard, 545 U.S. 374, 383 (2005) (reversing on the grounds that "the lawyers were deficient in failing to examine the court file on Rompilla's prior conviction"); Wiggins v. Smith, 539 U.S. 510, 524 (2003) (reversing based on counsel's decision not to expand the investigation beyond the 
is it to deny that, although some cases are focused on legal technicalities, others are centrally concerned with factual issues. But it is to deny that inquiry is quite as central to the law as it is to science.

Moreover, as Justice Blackmun intimates, the way our legal system goes about making its "determinations of the truth" is really quite unlike the processes of scientific investigation: the law relies on an adversarial procedure, subject to the relevant standard of proof, under the constraint of rules some of which mandate the exclusion of relevant evidence for reasons that are not even obliquely truth-related. And the advocacy that is at the core of the adversarial process is a very different matter from inquiry. Inquiry starts with a question and seeks out evidence, aiming to arrive at an answer; advocacy, aiming to persuade, starts with a proposition to be defended and marshals the best evidence it can in its favor. The obligation of a scientist, qua inquirer, is to seek out as much evidence as he possibly can and to assess it as fairly as possible. By contrast, the obligation of an attorney, qua advocate, is to make the best possible case for his client's side of the dispute-including playing up the evidence that favors his case, and explaining inconvenient evidence away if he can't get it excluded.

Some, taking for granted that the legal system is in the relevant respects in the same business as the sciences, object that it goes about that business in a peculiar and ineffective way. C.S. Peirce said this quite explicitly: "Some persons fancy that hot and partisan debate is the way to investigate. This is the theory of our atrocious legal procedure. But Logic puts its heel upon this suggestion." Judge Marvin Frankel is only a little more oblique: "We proclaim to each other and to the world that the clash of adversaries is a powerful means for hammering out the truth .... [But] [d] espite our untested statements of selfcongratulation, we know that others searching for the truth-in history, geography, medicine, whatever-do not emulate our adversarial system." ${ }^{\prime 68}$ If the legal system were in the same business as history, geography, or as physics and the other sciences, its way of conducting that business would be peculiar, and inefficient, to say the least. But the law is really not in exactly the same business.

This is not at all to deny that it is desirable that legal determinations of guilt or liability be, so far as possible, factually correct; on the contrary, it is highly

presentence investigation (PSI) and Department of Social Services (DSS) records, which "fell short of the professional standards that prevailed in Maryland in 1989"); Williams v. Taylor, 529 U.S. 362,373 (2000) (reversing the death penalty and remanding on the grounds that counsel for the petitioner had failed to seek Williams' juvenile and social-service records, "erroneously believ[ing] that 'state law didn't permit it"'); American Bar Association Guidelines for the Appointment and Performance of Counsel in Death Penalty Cases 11.4.1, 93 (1989) (instructing that counsel should make efforts to discover "all reasonably available mitigating evidence and evidence to rebut any aggravating evidence that may be introduced by the prosecutor").

67. Charles Sanders Peirce, 2 COLlected PaPers of Charles Sanders PeirCE para. 635 (Charles Hartshorne \& Paul Weiss eds., 1932) (the passage quoted is dated 1878).

68. Marvin F. Frankel, The Search for Truth: An Umpireal View, 123 U. PA. L. REV. 1031, 1036 (1975). 
desirable. But that "so far as possible" includes "consistent with satisfying such non-truth-related desiderata as reaching a resolution within a reasonable period of time, proceeding in accordance with constitutional constraints, and taking certain policy-related considerations into account." ${ }^{69}$ Given that the legal "quest for truth" must be conducted within a relatively short time frame, it could be argued that an adversarial system is a way of ensuring that the search for and scrutiny of evidence is as thorough as possible within those constraints; though only on certain assumptions, among them that the resources available to the parties are roughly equal-assumptions that, sad to say, only too rarely obtain. ${ }^{70}$

Implicit in the previous paragraphs, but needing to be made explicit, are the crucial differences between the legal and the scientific timetables. In the wake of a major discovery, scientific investigation sometimes advances at an impressive pace, rather as filling in a long, central crossword entry sometimes enables you to solve a whole slew of others; often, though, scientific work is halting and fumbling, slowed sometimes by lack of funds or by political resistance to potentially unwelcome results, and often enough by the sheer intellectual difficulty of the task. And there is always, at least in principle, the possibility of having to go back and start over on what had been thought to be settled questions. By contrast, not without reason, we want the legal system to reach its determinations within a reasonable period of time; and, again not without reason, we want those determinations, once the appeals process is exhausted, to stand.

Also implicit in the preceding paragraphs, and also needing to be made explicit, is that the legal process is highly regimented, conducted under formal rules of procedure, and rules of evidence, and so on. Paul Feyerabend, selfstyled "court jester" of the philosophy of science, wrote of the "methodological anarchism" of the sciences ${ }^{71}$ and despite his tendency to wild exaggeration, there is a grain of truth in this idea. It is not exactly that absolutely anything goes; but scientific inquiry does have a kind of free-ranging, "just do it," improvising character. By contrast, the regimented procedures of the law look more like a formal dance-a minuet, perhaps.

Also implicit, and also needing to be made explicit, is that some of the questions answers to which are to be determined at trial, will be case-specific: Did his mother's taking Bendectin cause Jeffrey Blum's birth defect? ${ }^{22}$ Did his

69. As Robert Heilbrun's fictional public defender Arch Gold comments, "[t]his [the capitalsentencing hearing in which he was participating] wasn't the real world.... It was a twisted kind of theater, a 'reality-based' drama that had nothing to do with what really went on down there on Twentieth Street." ROBERT HEILBRUN, OFFER OF PROOF 238 (2003).

70. The argument is developed, and its presuppositions explored, in Susan Haack, Epistemology Legalized: Or, Truth, Justice, and the American Way, 49 AM. J. JURIS. 43 (2004).

71. Paul K. Feyerabend, against Method: Outlines of an Anarchistic Theory of KNOWLEDGE 10 (1975) (claiming that "[s]cience is an essentially anarchistic enterprise"); see also HAACK, supra note 4, at 49-50 (criticizing Feyerabend's philosophy of science).

72. Blum v. Merrell Dow Pharms., Inc., 1 Pa. D. \& C.4th 634 (Pa. C.P. 1988), rev'd, 560 A.2d 212 (Pa. Super. Ct. 1989), aff'd 626 A.2d 537 (Pa. 1993), remanded to 33 Phila. 193 (Pa. C.P. 1996), rev'd 705 A.2d 1314 (Pa. Super. Ct. 1997), affm'd 764 A.2d 1 (Pa. 2000). 
occupational exposure to polychlorinated biphenyls (PCBs) promote $M r$. Joiner's cancer? ${ }^{73}$ What is the probability that the match between this DNA sample from the crime scene and this defendant is a matter of chance? Moreover, when they are not foreclosed by precedent, legal decisions will often be influenced by policy considerations, for legal concepts are often tinged with policy.

\section{IV}

\section{THOSE "IRRECONCILABLE DIFFERENCES" AT WORK}

Against this background we can readily see why, as Mr. Humes so bluntly puts it, "courts don't do science very well": ${ }^{74}$ why the law has such difficulty in handling scientific testimony, and so often gets less than the best out of science. ${ }^{75}$ But it is a very complicated, very tangled tale; for the tensions between science and law interact and reinforce each other. I had hoped to be able to shoehorn the difficulties into simple categories: "finality vs. fallibilism," "advocacy vs. inquiry," "inertia vs. innovation," and so on; but now this seems impossibly neat and tidy. Here, instead, is a not-so-tidy list.

(i) Because its business is to resolve disputed issues, the law very often calls on those fields of science where the pressure of commercial interests is most severe. In tort litigation, for example, much of the scientific work bearing on issues of causation may have been conducted by a drug company or a chemical manufacturer, for marketing purposes or, quite often, with an eye to protecting itself against litigation. This is exactly the kind of scientific work in which commercial interests most severely strain the informal scientific mechanisms that encourage honesty and discourage the withholding of evidence. I think in this context of the wave of litigation by plaintiffs alleging that their cardiovascular problems were aggravated by Merck's arthritis drug, Vioxx: for we now know that Merck's first large clinical trial, the VIGOR study, on the basis of which the FDA approved the drug, was designed in such a way as to be more likely to identify favorable than unfavorable trends ${ }^{76}$ and that the APPROVe study, which prompted the withdrawal of the drug, did not use the

73. Gen. Elec. Co. v. Joiner, 522 U.S. 136, 139-40 (1997).

74. HUMES, supra note 2, at 257.

75. Its interactions with the law can also have deleterious effects on science. For example, scientists whose work potentially bears on litigation are quite likely to find themselves interrupted and overburdened by subpoenas and depositions. Legal Demands Take Time from Scientists' Real Work, WALl ST. J., Jan. 27, 2007, at A5 (on file with Law and Contemporary Problems). But these issues cannot be pursued here.

76. The VIGOR study was designed to track gastrointestinal effects (anticipated to be favorable to the drug) longer than cardiovascular effects (anticipated to be unfavorable). Claire Bombadier et al., Comparison of Upper Gastrointestinal Toxicity of Rofecoxib and Naproxen in Patients with Rheumatoid Arthritis, 343 NEW ENG. J. MED. 1520 (2000); David Armstrong, How the New England Journal Missed Warning Signs on Vioxx: Medical Weekly Waited Years to Report Flaws in Article, WALL ST. J., May 15, 2006, at A1, A10; see also Haack, supra note 44, at 804-07; HAACK, supra note 53, at 116-20 (telling the Vioxx story). 
statistical method the published report of the study said it used, and would have been even less favorable to Vioxx if it had. ${ }^{77}$

(ii) Because the legal system aspires to resolve disputes promptly, ${ }^{78}$ the scientific questions to which it seeks answers will often be those for which all the evidence is not yet in. The cases that come to trial will normally be those in which the evidence is thus far incomplete and ambiguous. For one thing, plaintiffs must sue before the possibility of redress is legally foreclosed; for another, when the evidence that a drug or chemical is dangerous is overwhelming, plaintiffs' claims are likely to be settled out of court.

(iii) Because of its case-specificity, the legal system often demands answers of a kind science is not well-equipped to supply; for related reasons, the legal system constitutes virtually the entire market for certain fields of forensic science (or quasi-science), and for certain psychiatric specialties. The first point is wellillustrated in Joiner: by the time of Mr. Joiner's suit, the toxicity of PCBs was well-established; but how much, if at all, Mr. Joiner's occupational PCB exposure contributed to his developing lung cancer-given that he had been a smoker and that he had a family history of lung cancer-was an almost impossibly difficult question. ${ }^{79}$ The clearest illustrations of the second point come from such forensic-identification fields as hair or knife-mark analysis, ${ }^{80}$ and such psychiatric specialties as the recovery of supposedly repressed memories or, again, prediction of future dangerousness ${ }^{81}$ - surely among the weakest of what we sometimes call the "soft," or social sciences.

(iv) Because of its adversarial character, the legal system tends to draw in as witnesses scientists who are in a sense marginal-more willing than most of their colleagues to give an opinion on the basis of less-than-overwhelming evidence; moreover, the more often he serves as an expert witness, the more unbudgeably confident a scientist may become in his opinion. An attorney obligated to make

77. Scott D. Solomon et al., Cardiovascular Events Associated With Rofecoxib in a Colorectal Adenoma Prevention Trial, 352 NEw ENG. J. MED. 1092, 1093 (2005); Correction, 355 NEW ENG. J. MED. 221 (2006); Heather Won Tesoriero, Vioxx Study Correction May Add Pressure to Merck's Defense, WALL ST. J., June 27, 2006, at A2. In November 2007, Merck made a $\$ 4.85$ billion settlement deal with (a large class of) Vioxx plaintiffs. Heather Won Tesoriero, Sarah Rubenstein, \& Janey Heller, Vioxx Settlement for $\$ 4.85$ Billion Largely Vindicates Merck's Tactics, WALL ST. J., Nov. 11, 2007, at A1, A5.

78. I say "aspires" because, in practice, litigation is sometimes alarmingly protracted; for example, the Blums first brought suit against Merrell Dow in 1982, but the case was not finally resolved until 2000. See supra text accompanying note 72.

79. Gen. Elec. Co. v. Joiner, 522 U.S. 136, 139-40 (1997); see also Michael Gottesman, From Barefoot to Daubert to Joiner: Triple Play or Double Error?, 40 ARIZ. L. REV. 753, 766-76 (1998) (discussing causation evidence, in Joiner and more generally).

80. See, e.g., Adina Schwartz, A Systemic Challenge to the Reliability and Admissibility of Firearms and Toolmark Identification, 6 COLUM. SCI. \& TECH. L. REV. 2 (2005) (arguing that "all firearms and toolmark identifications should be excluded until adequate statistical empirical foundations and proficiency testing are developed for the field").

81. See, e.g., Thomas Regnier, Barefoot in Quicksand: The Future of Future Dangerousness Predictions in Death Penalty Sentencing in the World of Daubert and Kumho, 37 AKRON L. REV. 469 (2004) (discussing the scientific weaknesses of predictions of future dangerousness, and the role of such predictions in Texas death-penalty hearings). 
the best possible case for his client will have an incentive to call on those scientists who are ready to accept an answer to some scientific question as warranted when others in the field still remain agnostic; and sometimes on scientists whose involvement in litigation has hardened their initially morecautious attitudes into unwarranted certainty. I think, in this context, of Merrell Dow's Robert Brent, always ready to testify that Bendectin does not cause birth defects, ${ }^{82}$ and psychiatrist Dr. James Grigson, testifying over and over in Texas death-penalty hearings that the defendant would, to a psychiatric certainty, be dangerous in future. ${ }^{83}$

The adversarial process may distort even relatively strong science from relatively strong fields, sometimes to such a degree that it creates a kind of artificial scientific doubt, ${ }^{84}$ or artificial scientific certainty; and can generate a public perception that this product is well known to be dangerous, or that product well known to be harmless, when really the evidence is weak, ambiguous, or lacking. Public (mis?)perception that silicone breast implants cause systemic connective-tissue disorders, for example, may have been generated in part by the legal system. ${ }^{85}$

Adversarialism can also cause distortions in the forensic sciences, not only by encouraging the startling dogmatism with which knife-mark examiners, for example, routinely assert that they can make a match with one hundred percent

82. In Blum v. Merrell Dow Pharmaceuticals, Inc., 33 Phila. 193 (Pa. C.P. 1996), Merrell Dow's experts included Dr. Brent, who had not only testified over and over that Bendectin was not teratogenic, but had even published an article in which he analyzed seventeen Bendectin cases and concluded that every one of the plaintiffs had lied; and the Blums' experts included Dr. Alan Done, who had served as plaintiffs' expert in a number of Bendectin cases and, understandably troubled by some flaws in the clinical trials and animal studies on which the defendants relied, was willing to conclude that his mother's taking Bendectin while pregnant could have caused Jeffrey Blum to be born with clubbed feet. See also Susan Haack, What's Wrong with Litigation-Driven Science? An Essay in Legal Epistemology, 38 SETON HALL L. REV. 1053, 1063-69 (2008) (analyzing the expert evidence in Blum).

83. See Regnier, supra note 81 , at $480-82$ (describing the role of Dr. Grigson in Texas deathpenalty hearings).

84. See, e.g., David Michaels \& Celeste Monforton, Manufacturing Uncertainty: Contested Science and the Protection of the Public's Health and Environment, 95 AM. J. PUB. HEALTH (SUPPLEMENT 1) S39 (2005) (arguing that "opponents of public health and environmental regulation often try to 'manufacture uncertainty' by questioning the validity of scientific evidence on which the regulations are based").

85. One study found a statistically significant correlation between silicone breast implants and connective-tissue disorders; however, this study was seriously flawed, depending on subjects' own reports of their medical problems. Charles H. Hennekens et al., Self-reported Breast Implants and Connective-Tissue Diseases in Female Health Professionals, 275 J. AM. MED. Assoc. 616 (1996). In 1998, Judge Samuel Pointer's National Science Panel and, the following year an independent National Institute of Medicine Panel both reached the conclusion that there was no evidence that the implants cause such disorders. Report from National Science Panel, available at http://www.fjc.gov/BREIMLIT/SCIENCE/report.htm (last visited Nov. 4, 2008); Safety of Silicone Breast Implants (Stuart Bondurant, Virginia Ernster, \& Roger Herdman, eds.) 211-32 (2000) (concluding that "[t]he committee finds no convincing evidence for atypical connective tissue... disease in women with silicone breast implants"). 
certainty, and that they never make mistaken identifications ${ }^{86}$ but also by fostering the kinds of mistakes that can occur in the application even of scientifically very solid forensic-identification techniques, such as DNA analysis, when technicians are too anxious to be "helpful," to get the results law-enforcement needs. ${ }^{87}$

(v) Legal rules can make it impossible to bring potentially useful scientific information to light; and the legal penchant for rules, "indicia," and the like sometimes transmutes scientific subtleties into formulaic legal shibboleths. Courts' obligation to screen out unreliable scientific evidence has amplified the epistemological atomism of the rules of evidence, for judges rule not only on which proffered expert witnesses may testify, but also on whether they may testify to this or that question specifically. ${ }^{88}$ This can be a problem: for interlocking pieces of evidence (for example, toxicological information, animal studies, and epidemiological data), none of which is sufficient by itself, may jointly constitute adequate warrant for a claim that this exposure likely caused a plaintiff's injury ${ }^{89}$ but if no individual piece of it is deemed reliable enough to be admissible, a jury might never hear such evidence. The issue of "weight of evidence methodology" was explicit both in the Court of Appeals' reversal of the district court's exclusion of Mr. Joiner's expert testimony and in Justice Stevens's dissent in Joiner ${ }^{90}$ but it was already implicit in Daubert, having come

86. See Ramirez v. State, 810 So. $2 \mathrm{~d} 836,840-41$ (Fla. 2001) (reporting that expert witness Robert Hart's "specific knife mark identification evidence played a crucial role in the trial: [t] he trial court allowed the expert to state, 'The result of my examination made from the microscopic similarity, which I observed from both the cut cartilage and the standard mark, was the stab wound in the victim was made by this particular knife to the exclusion of all others."').

87. The story was extensively reported in the Houston Chronicle. See, e.g., Alan Bernstein, Crime Lab Scandal Leaves Prosecutor Feeling Betrayed: Owmby Says Sutton Case Tests Faith in Justice System, Hous. Chron., May 16, 2003, at A23; Roma Khanna \& Steve McVicker, HPD Ignored Warnings, Ex-Lab Man Says: Retired Official Says He Cited "Train Wreck," Hous. CHRON., June 23, 2003, at A1; Roma Khanna \& Steve McVicker, Police Chief Shakes Up Crime Lab; 2 Officials Quit, Others Disciplined, Hous. CHRON., June 13, 2003, at A1; Steve McVicker \& Roma Khanna, 3 Say Chief Knew of Lab Woes; Bradford Says Some Disgruntled Employees Trying to Discredit Him, Hous. CHRON., June 22, 2003, at A1; Steve McVicker \& Roma Khanna, 93 HPD Cases Under Scrutiny: Investigator's New Report Raises Figure From 27, HOUS. CHRON., May 11, 2006, at B1.

88. See, e.g., United States v. Llera-Plaza, Nos. CR. 98-362-10, CR. 98-362-11, 98-362-12, 2002 WL 27305 at $* 19$ (E.D. Pa. Jan. 7, 2002), vacated, 188 F. Supp. 2d 549 (E.D. Pa. 2002) (allowing FBI fingerprint examiners to testify about how they raised latent prints, about the characteristics of these latents from the crime scene, et cetera, but not to testify as to whether there was a match with the defendant).

89. See Susan Haack, Proving Causation: The Holism of Warrant and the Atomism of Daubert, $4 \mathrm{~J}$. HEALTH \& BIOMED. L. 253 (2008).

90. In Joiner v. General Electric Co., 864 F. Supp. 1310, 1324-26 (1994), the District Court, noting that none of the animal studies or the epidemiological studies on which Joiner's experts relied was sufficient by itself to establish that PCB exposure promoted his small-cell lung cancer, ruled that Joiner's expert testimony was inadmissible. In Joiner v. General Electric Co., 78 F.3d 524, 532 (11th Cir. 1996), the Court of Appeals reversed this decision, concluding that "[o]pinions of any kind are derived from individual pieces of evidence, each of which by itself might not be conclusive, but when viewed in their entirety are the building blocks of a perfectly reasonable conclusion ...." At the Supreme Court, Justice Stevens' endorsed this idea. Gen. Elec. Co. v. Joiner, 522 U.S. 136, 152 (1997). I am being deliberately noncommittal about whether the evidence Mr. Joiner's attorneys presented really did interlock in such a way as sufficiently to warrant his claim, in part because only part of that evidence is 
to the surface when, on remand, reasoning that each and every one of the Dauberts' experts would have to be excluded under Daubert as they had been under Frye, Judge Kozinski affirmed the district court's grant of summary judgment in favor of Merrell Dow."

Moreover, the legal system has a way of relying on brief verbal formulae to encapsulate key concepts or principles, to provide guidelines, and to give "indicia" of this or that. As a result, the law sometimes "rigidifies" ideas that scientists themselves treat much more flexibly. For example, though peerreviewed publication is now standard practice at scientific and medical journals, I doubt that many working scientists imagine that the fact that a work has been accepted for publication after peer review is any guarantee that it is good stuff, or that its not having been published necessarily undermines its value. ${ }^{92}$ The legal system, however, has come to invest considerable epistemic confidence in peer-reviewed publication ${ }^{93}$ - perhaps for no better reason than that the law reviews are not peer-reviewed! Again, though requiring statistical significance is now also routine scientific practice, most scientists are probably aware of the element of arbitrariness in the usual standards, $;^{94}$ but legal actors sometimes seem to invest statistical significance with-well, with undue significance. And the law sometimes tinges scientific concepts with policy considerations-which partly explains why, for example, legal and scientific conceptions of causation don't quite mesh: the legal conception is informed by considerations about incentives and disincentives, about who should bear the costs of potentially risky enterprises, and sometimes about whose fault it is that evidence is lacking - considerations quite alien to science.

And the brief verbal formulae on which the law often relies can be ambiguous. For example, Justice Blackmun's observations about "peer review and publication" could be taken as requiring that scientific testimony be based on work that has survived the pre-publication peer-review process of scientific journals-which is relatively easy for a court to determine, but a poor indication

described in the Court's ruling in Joiner. In any case, the point here is only that evidence may interlock in this way, and that evidence law may prevent this from becoming apparent.

91. Daubert v. Merrell Dow Pharms., Inc., 43 F.3d 1311, 1310-12 (9th Cir. 1995).

92. For example, the scientists on Judge Pointer's National Science Panel (set up to sift through the evidence about silicone breast implants and connective-tissue disorders) included unpublished dissertations and letters, as well as published material, as providing evidence relevant to their task. Submission of Rule 706 National Science Panel Report, In Re Silicone Gel Breast Implant Product Liability Litigation, No. CV 92-P-10000-S, 8 (N.D. Ala. Dec. 1, 1998), available at www.fjc.gov/BREIM LIT/SCIENCE/report.htm (last visited Oct. 26, 2008).

93. The legal preoccupation extends beyond issues of scientific testimony; for example, in Kitzmiller v. Dover Area School District, 400 F. Supp. 2d 707, 735 (M.D. Pa. 2005), that there were no publications on Intelligent Design Theory in peer-reviewed scientific journals was taken as an indication that IDT is not science, but religion.

94. Reviewers for the Journal of the American Medical Association imposed a higher than usual standard of statistical significance in assessing the recent re-analysis of the Women's Health Initiative data on hormone-replacement therapy. Tara Parker Pope, New Study Reassures Most Users of Hormones, WALL ST. J., Apr. 4, 2007, at A1, A12.

95. Daubert v. Merrell Dow Pharms., Inc., 509 U.S. 579, 593-94 (1993). 
of reliability. Or they could be taken as requiring that such testimony be based on work that has survived and will continue to survive the long-run scrutiny of scientists in the field-which is a better (though still imperfect) indication of reliability, but impossible for a court to determine. ${ }^{96}$ There is a similar ambiguity in Judge Kozinski's fifth "Daubert factor": whether the work on which scientific testimony is based is "litigation-driven." "' It is reasonably easy for a court to determine whether the work on which testimony is based was undertaken after litigation began, but this is a very weak indicator of unreliability; whether the design or interpretation of the work on which the testimony is based was significantly affected by litigation-related considerations is a better indication of unreliability, but this is much harder for a court to determine. ${ }^{98}$

(vi) Both because of its concern for precedent, and because of the desideratum of finality, the legal system has a tendency to inertia, and sometimes lags behind science. The novel scientific testimony excluded by the Frye court was proffered by the defense: Mr. Frye had passed a then-new blood-pressure deception test, "monograph" evidence, you might say; but by the time Florida first endorsed the Frye test in Kaminski, what was at stake was the admissibility of polygraph evidence. ${ }^{99}$ The introduction of DNA "fingerprinting" in the late 1980s met with significant resistance in the ensuing "DNA Wars"; and even after the reliability of DNA analysis and its power to enable justice was acknowledged, prosecutors pushed back against requests for post-conviction testing. ${ }^{100}$ One might conjecture that Daubert and, especially, Joiner would have lessened the tendency for courts to follow other courts' rulings about the reliability of this or that kind of scientific evidence; but some commentators argue that Joiner has led judges who feel uneasy about the possibility that the very same evidence might be ruled reliable by one court and unreliable by

96. See HAACK, supra note 44, at 791, 808-15 (distinguishing the two senses of "peer review" and tracing the consequences of this ambiguity).

97. Daubert v. Merrell Dow Pharms., Inc., 43 F.3d 1311, 1317 (9th Cir. 1995).

98. See Haack, supra note 82, at 1078-81 (distinguishing the two senses of "litigation-driven").

99. Kaminski v. State, 63 So. 2d 339, 340 (Fla. 1952) (ruling lie-detector evidence inadmissible, and citing Frye, but without specifying the nature of the lie-detector technology at issue); Don Grubin \& Lars Mardin, Lie Detection and the Polygraph: A Historical Review, 16 J. FORENSIC PSYCHIATRY \& PSYCHOL. 357, 359-60 (reporting that the systolic-blood-pressure deception test at issue in Frye was devised by William Marston in 1915; that John Larson developed the first modern polygraph machine (measuring blood pressure, pulse rate, and respiration rate) in 1921; and that in 1939 Leonarde Keeler added the galvanic-skin-response channel to the polygraph).

100. See e.g., David LAZER, DNA AND the CRIMINAl Justice System: The Technology of JUSTICE 5 (2004) (writing of the "lack of receptivity of the system to post-conviction application of DNA analysis"); MARGARET BERGER, Lessons from DNA: Restriking the Balance between Finality and Justice, in LAZER, supra, at 109, 120 ("Prosecutors have been reluctant to report possible failing in the laboratory...."). But see Anna S. Leggett \& Joseph L. Peterson, The Evolution of Forensic Science: Progress Amid the Pitfalls, 36 STETSON L. REV. 621, 630 (2007) ("Soon after DNA evidence's initial introduction to courts in the mid-1980s, defense attorneys mounted a more vigorous challenge to prosecution test results ...."). 
another in the same jurisdiction to treat such evidentiary rulings as precedential. $^{101}$

\author{
V
}

\title{
CAN THIS MARRIAGE BE SAVED?
}

Obviously, divorce is out of the question; the law can't do without scientific testimony.

Both partners have tried to adapt. For example, there have been small but significant legal changes, including extensions of the statute of limitations to enable the prosecution of long-ago crimes when the perpetrator can now be identified by DNA analysis, or to enable testing of samples that might exonerate those already convicted-small compromises of the law's concern for promptness and finality; and there has been a modest increase in courts' use of their power to appoint their own experts-a small compromise of adversarialism. And on the scientific side, besides efforts to provide legally relevant scientific education for judges, there is, for example, the CASE (Court Appointed Scientific Expert) Project initiated by the AAAS (American Association for the Advancement of Science) in 1999 to provide "independent scientists who would educate the court, testify at trial, assess the litigants' cases, and otherwise aid in the process of determining the truth," 102 and the Registry of Independent Scientific and Technical Advisors set up by Duke University School of Law. ${ }^{103}$

Not surprisingly, however, such adaptations don't always work out quite as planned. The AAAS has learned that, quite often, when a judge announces that he will seek their advice in identifying independent experts, the upshot is not that CASE experts are appointed, but that the case is promptly settled. ${ }^{104}$ And judges have learned that there is no guarantee that court-appointed experts will agree among themselves; in Soldo v. Sandoz Pharmaceuticals, Inc., for example, two of three court-appointed experts concluded that the methodology the plaintiff's expert witnesses had used in arriving at the opinion that Ms. Soldo's stroke had been caused by the anti-lactation drug Parlodel was not reliable, but

101. See Heinzerling, supra note 46, at 81 (arguing that "[o]ne consequence of this lax [abuse of discretion] standard of review is that district judges may come to different conclusions on the same evidence .... One can imagine, therefore, the (perhaps unconscious) desire of judges to tidy up this mess by applying stare decisis principles to evidentiary rulings").

102. Doug Bandow, Keeping Junk Science Out of the Courtroom, WALL ST. J., July 26, 1999, at A23.

103. Sometimes, also, scientific bodies have disciplined members for their testimony in court: for example, in 1995 the American Psychiatric Association expelled Dr. Grigson for his irresponsible testimony in Texas death-penalty cases. Laura Bell, Groups Expel Psychiatrist Known for Murder Cases, Dallas Morning News, July 26, 1995, at A21; "Dr. Death" Loses 2 Memberships Over Ethics Accusations, FORT WORTH STAR-TElEGRAM, July 27, 1995, at A25. Subsequently, Dr. Grigson continued to testify, mostly for the defense, but in at least two instances for the prosecution. Wesbrook v. State, 29 S.W.3d 103 (Tex. Crim. App. 2000); Wood v. State, 18 S.W.3d 642 (Tex. Crim. App. 2000).

104. As I learned from Dr. Mark Frankel (Director of the CASE Project) at a workshop at Albany Law School in December 2006. 
the third concluded that it was. ${ }^{105}$ (The court granted summary judgment to the defendant. $)^{106}$

Just as I began writing this paper when I had little more than the title, a local radio station began playing Beatles music all day long; and I toyed with the idea of entitling the last section, "We Can Work It Out." A nice idea; but it would have promised more than I can deliver. Still, let me try, at least, to suggest what might be fruitful ways to think about the problems diagnosed here. In Defending Science I wrote that, rather than expend all our ingenuity and energy on trying to refine legal rules on expert testimony, we might do better to consider other ways of mitigating the tensions; ${ }^{107}$ now I will add that it seems desirable-given that no complete or perfect solution is likely to be forthcoming - to think about what the most significant concerns are, and what could be done about these.

One major concern is that, whatever the effect of Daubert in civil cases, it has had startlingly little effect on issues about forensic testimony in criminal cases $^{108}$ - though we have ample reason to believe that such testimony is at best variable in quality. In a Frye state like Florida, criminal-defense attorneys sometimes speculate wistfully about how much better things would be in a Daubert jurisdiction; but it is not easy to share their optimism. "The only way to guard against the misapplication of forensic science is to impose controls and reforms long before the cases come to court," writes Peter Neufeld. ${ }^{109}$ Whether or not this is the only way, it is hard to deny that it might well be a better way. In the case of DNA identification, where there is solid underlying science, the most important thing is to ensure that the techniques are not misapplied through haste, sloppiness, mismanagement, or dishonesty, conscious or unconscious. In the case of latent-fingerprint- or knife-mark identifications and the like, however, where the underlying science is weak or nonexistent, the first thing is to find out just how reliable such identifications are.

Another major concern is highlighted by Justice Breyer's observation about trying to ensure that the "powerful engine" of tort litigation is directed, not at harmless and useful products, but at harmful stuff ${ }^{10}$ - this in his concurring opinion in Joiner, of all places, where the stuff in question was PCBs, so toxic they had already been banned for decades! What we want is, so far as possible,

105. Soldo v. Sandoz Pharms. Corp., 244 F. Supp. 2d 434, 503-04 (W.D. Pa. 2003); Soldo v. Sandoz Pharms. Corp., No. 98-1712, 2003 WL 22005893, gl 732 (W.D. Pa. Jan. 13, 2003) (order filing reports of court-appointed experts David Flockhart, William J. Powers, and David Savitz as part of the record).

106. Soldo, 244 F. Supp. $2 \mathrm{~d}$ at 577.

107. HAACK, supra note 4, at 256.

108. For example, by the time of United States v. Llera-Plaza, Nos. CR 98-362-10, CR 98-362-11, CR 98-362-12, 2002 WL 27305, at "19 (E.D. Pa. Jan. 7, 2002), vacated, 188 F. Supp. 2d 549 (E.D. Pa. 2002), there had been more than forty Daubert challenges to latent-fingerprint identification testimony, but none had succeeded. Six weeks later, in United States v. Llera Plaza, 188 F. Supp. 2d 549 (E.D. Pa. 2002), Judge Pollack reversed his restriction of such testimony.

109. Peter J. Neufeld, The (Near) Irrelevance of Daubert to Criminal Justice and Some Suggestions for Reform, 95 AM. J. PUB. HEALTH (SUPPLEMENT 1) S107, S107 (2005).

110. Gen. Elec. Co. v. Joiner, 522 U.S. 136, 148-49 (1997). 
to prevent dangerous stuff from coming on the market, and to do this without discouraging the production of useful and harmless stuff; and to ensure that, if dangerous stuff does creep in and people are damaged, the victims are taken care of, and the danger of future injury promptly averted. I suspect that we rely too much on the tort system-which seems in practice, to be something of a lottery, and which, in any case, surely ought to be the very last resort-when we ought to be asking about other ways of achieving those highly desirable ends. Maybe we could learn something from the experiences of other countries that are equally technologically advanced, but have different regulatory and legal arrangements; certainly, we would do well to approach these problems in a more empirical, experimental-a more scientific-spirit. 